\title{
VARIATION IN VEGETATION COVER OF SHRUB AS A VEGETATION CANDIDATE FOR GREEN OPEN SPACE COMPONENT IN CEMPAKA SUBDISTRICT, BANJARBARU
}

\author{
Dienny Redha Rahmani ${ }^{1}$, Gunawan², Setia Budi Peran ${ }^{3}$ \\ ${ }^{1}$ Graduate Program of Natural Resources and Environmental Management \\ email:dn.redha@gmail.com \\ 2Department of Biology, Faculty of Mathematics and Natural Sciences \\ ${ }^{3}$ Forestry Faculty \\ Lambung Mangkurat University, Banjarbaru, South Kalimantan
}

\begin{abstract}
Good urban structure and activity require green open space to improve the ecological functions in it, but trees are not fully able to meet the important space in the urban vegetation while woody shrubs have the potential for it. Therefore, the objective of this study was to find out the potential of shrub as the component of urban vegetation so that it can be used as the information regarding the planning for land conversion in Cempaka subdistrict. Three sampling stations with 3 plots of $4 \times 4 \mathrm{~m}$ at each station were determined on the basis of green open space data of shrubs in Cempaka subdistrict using a purposive sampling method. The shrub canopy was analyzed and environmental parameters were measured. Data were analyzed using the analysis of canopy volume, Pearson correlation analysis and analysis of Importance Value Index (IVI). The results of shrub vegetation estimation indicated that the volume of shrub vegetation canopy in Cempaka subdistrict was up to $22,462,878.50 \mathrm{~m}^{3}$ while the area with shrubs in the subdistrict was 5,675.116 hectares. Pearson correlation analysis showed that the canopy volume of shrubs in Cempaka subdistrict affected the changes in environmental factors. The most dominant shrub species was Ficus fistulosa Reinw. ex $\mathrm{BI}$ with IVI value of $56.1 \%$. It can be concluded that shrubs have potential as the component of the green space vegetation in urban areas.
\end{abstract}

Keywords: canopy, canopy volume, green open space, shrub, urban vegetation

\section{INTRODUCTION}

High level of urbanization today results in more dense urban areas. This will lead to the increasing negative effects, such as urban noise and urban pollution. Botkin \& Edward (2000) suggest that the urban has changed the landscapes such as forests, and also changed the relationship between biological and physical aspects of the environment.

Land-use planning is very important as the control of so much interest in city planning because the most important is the presence of green open spaces around the city (Koomen et al., 2010). The tendency of concentrating economic activities in urban areas encourages the mobilization of rural populations to urban areas. In line with the increase in economic activities, the pressure on the environment is even more severe, that has potential to the misallocation of space utilization which harms the interests of the urban living environment (Nandi 2007).

Under the law of Republic of Indonesia Number 26 of 2007 regarding the arrangement of space, every town should have a green open space planning (Republic of Indonesia, 2007). In this regard, Banjarbaru has had an urban planning for the provision of green open spaces around the area of Banjarbaru by the Local Government Regulation of Banjarbaru No. 5 of 2001 regarding the General Plan of Urban Spatial. One of the areas that will use the concept of green space in its development planning is Cempaka subdistrict (Banjabaru Municipality, 2001).

Cempaka subdistrict has high potential for green open space, based on the government data for green open space in Banjarbaru. Cempaka is also one of the largest oxygen subsidies for Banjarbaru (Banjabaru Municipality, 2001). In addition, based on aerial photos of vegetation index data of Banjarbaru Municipality, shrubs in this area has the possibility of becoming one of the dominant plant species (Banjarbaru Municipality, 2007). 
Bush or shrub is an element whose existence is necessary and important for green open space (Nugrahini, 2006). According to Werdiningsih (2007) shrub is a type of vegetation that has high weather resistance, but also has a rapid growth rate. Therefore, it is necessary to study the potential of shrub vegetation as a component of green open space in Cempaka subdistrict, Banjarbaru.

\section{MATERIALS AND METHODS}

The study was conducted in Cempaka subdistrict, Banjarbaru, by determining three sampling stations as media for representing the data of Cempaka's green open spaces. The determination of the sampling stations was carried out based on the map of shrub land cover of Banjarbaru. Three plot spots were then determined for each station, and a plot with a size of $4 \mathrm{~m} \times 4 \mathrm{~m}$ was created in order to count the number of shrubs in the plot.

\section{Estimation of Shrub Vegetation Canopy}

Number of shrub vegetation canopy was estimated based on Arlt et al. (2008) to measure the height of stems from ground level to canopy tip. The canopy height was then measured from the bottom to the top of canopy. Furthermore, the type of canopy was determined by the analogy of canopy shape in accordance with the volume of space, which was then fitted, based on the map of shrub land cover in Cempaka (Figure 1) from Banjarbaru Municipality ${ }^{1}$ (2007) with ArcView GIS software to determine the extent of the area covered by shrubs.

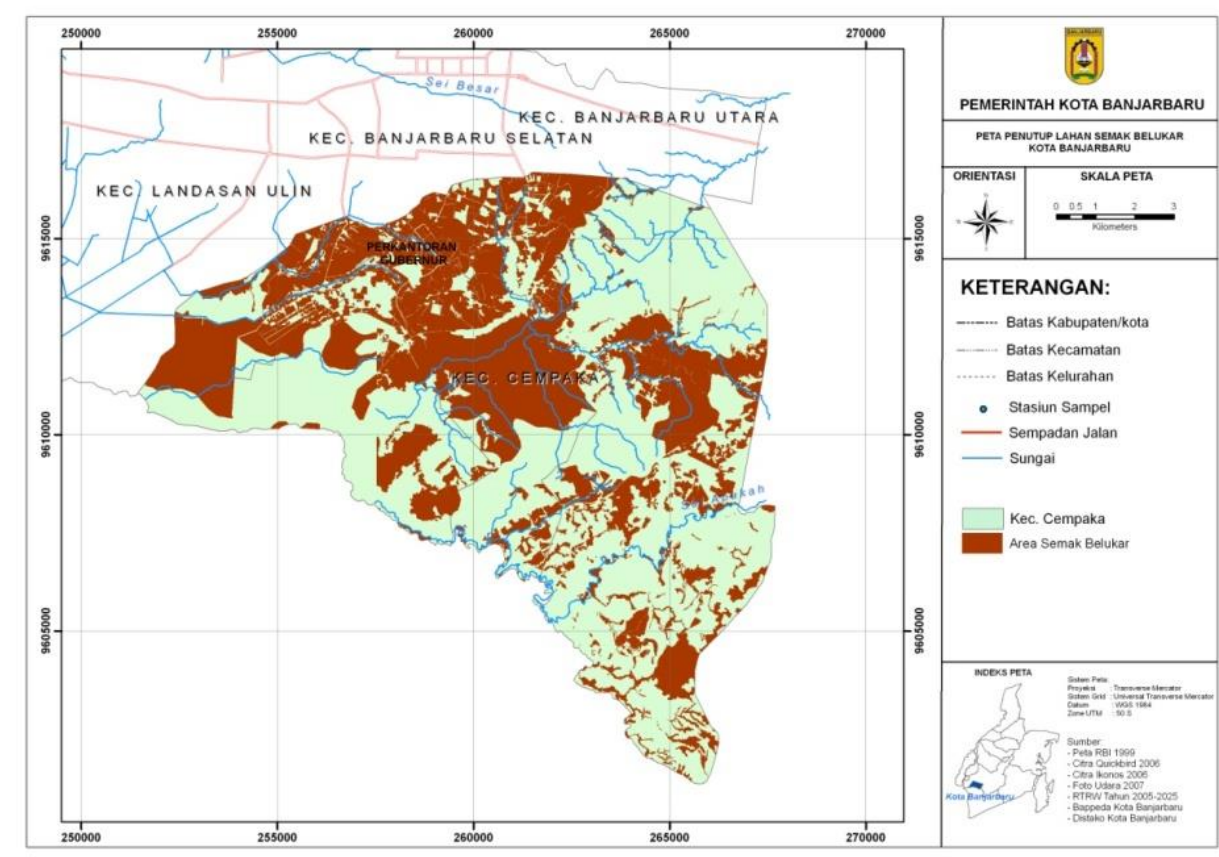

Figure 1. Map of shrub land cover in Cempaka subdistrict (Banjarbaru municipality, 2007)

\section{Measurement of Environmental Parameters}

Environmental parameters that were measured were temperature and humidity. The measurements, which were carried out at each sampling plot, were conducted in the middle of the plot with the waiting time of \pm 5 minutes to show a stable value on the device used.

\section{Identification of Shrub Vegetation}

The shrub species that were most commonly found or dominating, and other species which were also found at the location were identified by comparing them with the identification book based on the identification keys or references on plant morphology. The identification was carried out to the level of at least families.

\section{Data analysis}

Data obtained from the field were analyzed using three types of analysis: the analysis of canopy volume (Arlt et al., 2008) to determine the width of shrub canopy and analysis Importance Value Index (IVI), followed by the analysis of environmental factors. 
The area of canopy was analyzed with Arlt et al. (2008) using the formula of canopy volume (Table 1).

Table 1. Formula of canopy dimension (Arlt et al, 2008)

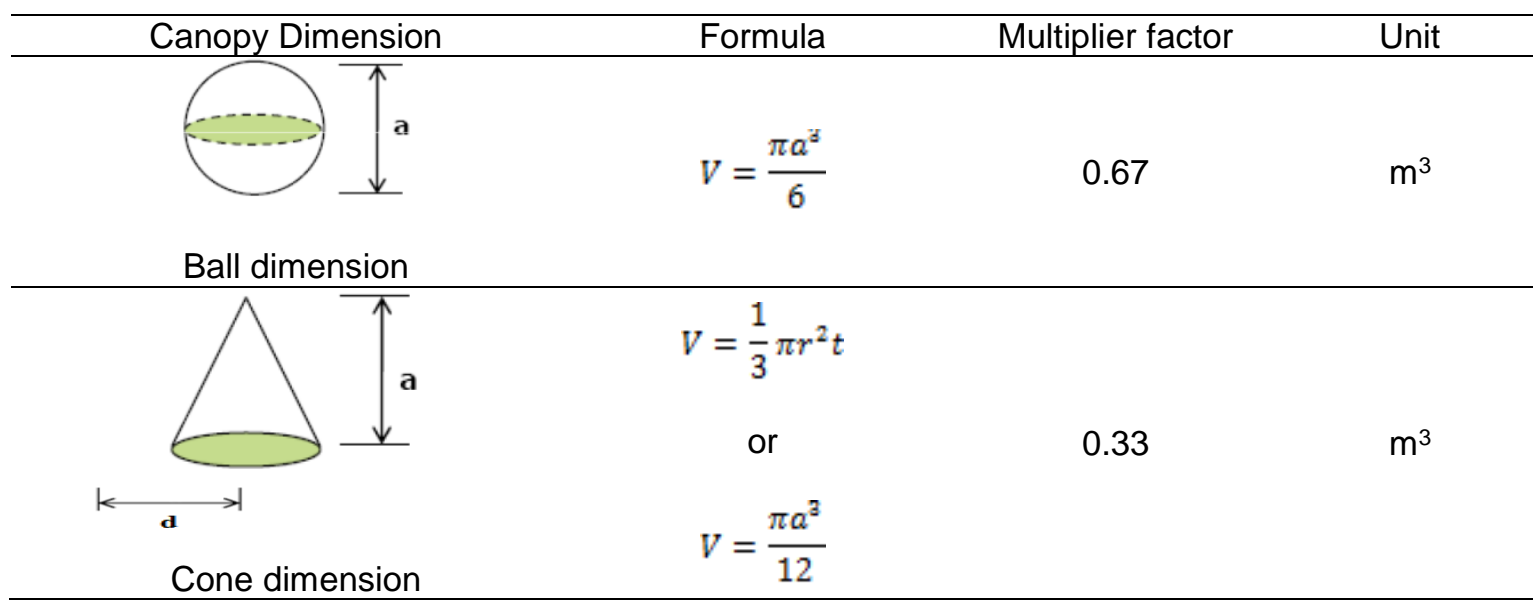

Importance Value Index (IVI) of each species found in one plot was analyzed using the following formula:

$\begin{array}{lll}\text { Note: } & & \mathrm{IVI}=\mathrm{RD}+\mathrm{RF}+\mathrm{RDm} \\ \mathrm{IVI}= & \text { Importance Value Index } \\ \mathrm{RD}= & \text { Relative Density } \\ \mathrm{RF}= & \text { Relative Frequency } \\ \mathrm{RDm}= & \text { Relative Dominance }\end{array}$

Data of environmental factors were analyzed using descriptive statistics. The correlation and relationship between environmental factors (temperature and humidity) and the width and volume of shrub canopy were analyzed with a correlation analysis.

\section{RESULTS AND DISCUSSION}

\section{Analysis of Canopy Volume and Environmental Factors}

Data used to analyze the canopy volume were canopy height, canopy width and description of space volume types formed by the shrub canopy. Based on the analysis of shrub canopy, the total volume of shrubs in Cempaka area with the extensive vegetation cover of 5,675.116 $\mathrm{H}$ reached $22,462,878.50 \quad \mathrm{~m}^{3} \quad$ (Table 2).

Table 2. Volume of shrub canopy

\begin{tabular}{ccc}
\hline Station & Plot & $\begin{array}{c}\text { Canopy volume } \\
\left(\mathrm{m}^{3}\right)\end{array}$ \\
\hline I & 1 & 0.15 \\
& 2 & 5.12 \\
& 3 & 1.99 \\
\hline II & 1 & 5.16 \\
& 2 & 0.72 \\
& 3 & 5.12 \\
\hline III & 1 & 22.33 \\
& 2 & 12.40 \\
& 3 & 4.00 \\
\hline Average & $\left(\mathrm{m}^{3}\right)$ & 6.33 \\
\hline Total Volume of Shrubs & $\left(\mathrm{m}^{3}\right)$ & $22,462,878.50$ \\
\hline
\end{tabular}


The environmental parameters measured were temperature and humidity. The measurements were performed in the morning, afternoon, and evening. The timing was aimed to know the difference of environmental conditions of each time period and whether there was a link with the canopy volume formed over the region (Table 3).

Table 3. Results of environmental parameter measurements

\begin{tabular}{cccccccc}
\hline \multirow{3}{*}{ Station } & & \multicolumn{3}{c}{ Temperature $\left({ }^{\circ} \mathrm{C}\right)$} & \multicolumn{4}{c}{ Humidity (\%) } \\
\cline { 3 - 8 } & Plot & \multicolumn{3}{c}{ Time } & & \multicolumn{3}{c}{ Time } \\
\cline { 3 - 8 } & & Morning & Afternoon & Evening & Morning & Afternoon & Evening \\
\hline \multirow{2}{*}{ I } & 1 & 24 & 30 & 27 & 73 & 62 & 68 \\
& 2 & 21 & 28 & 24 & 79 & 63 & 79 \\
& 3 & 22 & 29 & 26 & 77 & 63 & 78 \\
\hline \multirow{2}{*}{ II } & 1 & 21 & 29 & 24 & 79 & 63 & 79 \\
& 2 & 27 & 29 & 26 & 73 & 62 & 68 \\
& 3 & 22 & 28 & 24 & 79 & 63 & 79 \\
\hline \multirow{2}{*}{ III } & 1 & 20 & 27 & 22 & 82 & 68 & 80 \\
& 2 & 20 & 28 & 22 & 80 & 67 & 80 \\
& 3 & 22 & 29 & 26 & 78 & 67 & 78 \\
\hline
\end{tabular}

Each of the environmental factors (temperature and humidity) was correlated with canopy volume in each plot with a $95 \%$ confidence level. The purpose of the analysis was to find out whether there was a relationship between the canopy volume of shrubs and changes in the surrounding environment factors. The analysis showed that there was a relationship between the thickness of the canopy volume and the temperature and humidity in three different time periods. It was indicated by the significance value $<0.05$, indicating significant. The only time where the canopy volume was not significant or showed no visible association was for the air humidity in the afternoon indicated by the significance value $>0.05$, namely 0.103 .

The results of the measurements showed that the temperature varied inversely with humidity because at every station with different vegetation thickness showed changes or differences in moisture leading to different temperatures depending on the humidity of the air. This relationship is in accordance with Suarez et al. (2007) stating that the high air humidity in vegetation is associated with a drop in the temperature around the canopy; the lower the temperature, the higher the humidity generated. The sampling station which had large canopy volume was station 3 with the volume on plot 1,2 , and 3 of $22.33 \mathrm{~m}^{3}, 12.40$ $\mathrm{m}^{3}$, and $4.00 \mathrm{~m}^{3}$, respectively. The air humidity at this station was the highest compared to stations 1 and 2 , resulting in low temperature around the location. In this case, the canopy volume can influence environmental factors and the humidity is inversely proportional to the temperature. The relationship between the canopy volume and environmental factors in detail was analyzed by Pearson correlation analysis for each sampling time.

The correlation analysis was performed for each sample in order to find out the time when the canopy volume affected the environmental factors. The results of the correlation analysis (Table 4) at each sampling time showed that at the three time periods, the canopy volume had a relationship with their environment. It is based on a significance value $<0.05$, which meant that the canopy volume was related to or had an influence on the environmental factors.

\section{Analysis of Importance Value Index (IVI)}

Based on the results of the shrub identification, there were 6 species found at the sampling plots (Table 4). The highest IVI was in Ficus fistulosa Reinw. ex BI with IVI value of $56.1 \%$ (Table 5 ). This value showed that Ficus fistulosa Reinw. ex Bl probably had high distribution of frequency, and density compared to other species. 
Ochthocharis sp. had the second highest IVI after Ficus fistulosa Reinw. ex Bl. However, the relative frequency $(\mathrm{RF})$ was in Batis pigeon. This could happen because Ochthocharis sp. had a distribution type of cluster that can be seen in Table 4; this species was only found in station 1 on all plots, but it was not found at any other sampling stations. The third highest IVI, reaching $40.2 \%$, was Family Combretaceae because the distribution type of this species was random, not cluster. These values showed that Combretaceae had high frequency and density in the area of Cempaka subdistrict.

\section{Potential of Shrubs as Urban Vegetation Component}

Several analyses used to explore the potential of shrubs in the area of Cempaka showed that the shrub vegetation in this area had potential as one of the component of urban vegetation. According to Ballard et al. (2004) woody shrub has a height of less than 6 meters, so it can be in the shade under the cable connecting the power plant while the tree having a height of more than 6 meters can be harmful to the electricity network above it (Figure 2). One of the real forms of this potential is the formation of a microclimate around the land so that it can be used under the connecting power.

Table 4. Shrub species in Cempaka and their distribution

\begin{tabular}{|c|c|c|c|c|c|c|c|c|c|c|}
\hline \multirow{2}{*}{ Shrub species } & \multicolumn{3}{|c|}{ Station 1} & \multicolumn{3}{|c|}{ Station 2} & \multicolumn{3}{|c|}{ Station 3} & \multirow{2}{*}{ Number } \\
\hline & 1 & 2 & 3 & 1 & 2 & 3 & 1 & 2 & 3 & \\
\hline $\begin{array}{l}\text { Karamunting duduk } \\
\text { (Ochthocharis sp.) }\end{array}$ & 14 & 50 & 33 & 0 & 0 & 0 & 0 & 0 & 0 & 97 \\
\hline $\begin{array}{l}\text { Katuk Gunung } \\
\text { (Sauropus sp.) }\end{array}$ & 0 & 0 & 0 & 4 & 10 & 0 & 0 & 0 & 0 & 14 \\
\hline $\begin{array}{l}\text { Luwa } \\
\text { (Ficus fistulosa Reinw. ex BI) }\end{array}$ & 0 & 0 & 0 & 7 & 0 & 0 & 11 & 58 & 37 & 113 \\
\hline $\begin{array}{l}\text { Senggani } \\
\text { (Melastoma polyantum) }\end{array}$ & 0 & 0 & 0 & 0 & 11 & 21 & 0 & 0 & 0 & 32 \\
\hline $\begin{array}{l}\text { Pecah Belanai } \\
\text { (Fam. Combretaceae) }\end{array}$ & 0 & 0 & 0 & 12 & 7 & 4 & 8 & 29 & 0 & 60 \\
\hline $\begin{array}{l}\text { Batis punai } \\
\text { (Cassia sp.) }\end{array}$ & 0 & 0 & 0 & 3 & 0 & 0 & 6 & 0 & 9 & 18 \\
\hline
\end{tabular}

Table 5. Results of Importance Value Analysis

\begin{tabular}{lccccccc}
\hline \multicolumn{1}{c}{ Shrub } & $\begin{array}{c}\text { Width } \\
\text { of } \\
\text { area } \\
\left(\mathrm{m}^{2}\right)\end{array}$ & $\begin{array}{c}\text { Number of } \\
\text { Species }\end{array}$ & $\mathrm{K}$ & $\begin{array}{c}\mathrm{RD} \\
(\%)\end{array}$ & $\mathrm{F}$ & $\begin{array}{c}\mathrm{RF} \\
(\%)\end{array}$ & IVI (\%) \\
\hline $\begin{array}{l}\text { Karamunting duduk } \\
\text { (Ochthocharis sp.) }\end{array}$ & 144 & 97 & $\begin{array}{c}0.6 \\
7\end{array}$ & 29 & $\begin{array}{c}0.3 \\
3\end{array}$ & 16.7 & 45.7 \\
\hline $\begin{array}{l}\text { Katuk Gunung } \\
\text { (Sauropus sp.) }\end{array}$ & 144 & 14 & 0.1 & 4.19 & $\begin{array}{c}0.2 \\
2\end{array}$ & 11.1 & 15.3 \\
\hline $\begin{array}{l}\text { Luwa } \\
\text { (Ficus fistulosa Reinw. ex BI) }\end{array}$ & 144 & 113 & $\begin{array}{c}0.7 \\
8\end{array}$ & 33.8 & $\begin{array}{c}0.4 \\
4\end{array}$ & 22.2 & 56.1 \\
\hline $\begin{array}{l}\text { Senggani (Melastoma } \\
\text { polyantum) }\end{array}$ & 144 & 32 & $\begin{array}{c}0.2 \\
2\end{array}$ & 9.58 & $\begin{array}{c}0.2 \\
2\end{array}$ & 11.1 & 20.7 \\
\hline $\begin{array}{l}\text { Pecah Belanai } \\
\text { (Fam. Combretaceae) }\end{array}$ & 144 & 60 & $\begin{array}{c}0.4 \\
2\end{array}$ & 18 & $\begin{array}{c}0.4 \\
4\end{array}$ & 22.2 & 40.2 \\
\hline $\begin{array}{l}\text { Batis punai } \\
\text { (Cassia sp.) }\end{array}$ & 144 & 18 & $\begin{array}{c}0.1 \\
3\end{array}$ & 5.39 & $\begin{array}{c}0.3 \\
3\end{array}$ & 16.7 & 22.1 \\
\hline \begin{tabular}{l} 
Number \\
\hline
\end{tabular} & 864 & 334 & $\begin{array}{c}2.3 \\
2\end{array}$ & 100 & 2 & 100 & 200 \\
\hline
\end{tabular}




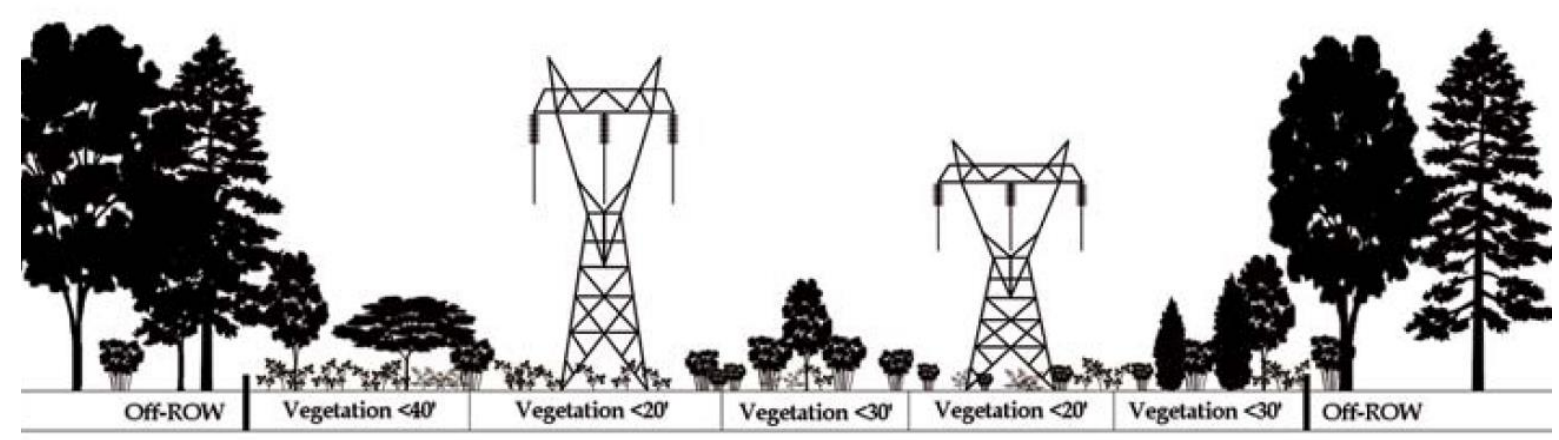

Figure 1. Concept of plant arrangement around urban area (Ballard et al., 2004)

The large canopy volume formed by Arlt et al. (2008) also became an indicator of the potential of a plant. Potential in the form of canopy volume has a lot of good ecological functions and other functions related to human activities. The potential for ecological functions can be natural green space, as the natural cover when there are no trees growing around the land or became the vegetation component as one of the vegetation levels.. Other functions for humanbeings are that it can be dust and noise filters and has the possibility as depositary of carbon and one of oxygen subsidies for the vegetation to the surrounding area.

The analysis of the potential of shrubs in vegetation indicated that shrubs have an important role in the greening of city either in mixed vegetation or in vegetation filled with shrub species. The utilization of the shrub role, for example in greening the city, has been carried out in Australia as revealed by Rawlings (2000), the Greening in the New South Wales Australia, including woody shrub regeneration, revegetation, tree planting, and urban forests.

\section{CONCLUSION}

Shrub vegetation has potential as a component of green open space in urban areas. Shrub has the potential to replace tree as a component of green space, in function of the land associated with the city's infrastructure (buildings, electrical installations, etc.), forming a micro climate.

\section{REFERENCES}

Arlt, G., Lehmann, I., and Deilmann, C. (2008). Urban Green Volume - A Quality Indicator. Leibniz Institute of
Ecological and Regional
Development, German.

Ballard D. B., Heather L. W., Christopher A. N. (2004). Northeastern Shrub and Short Tree Identification: A Guide for Right-of-Way Vegetation Management. Eastwood Litho, New York.

Botkin, D.B. and Edward, A.K. (2000). Environmental Science $3^{\text {rd }}$ edition: Earth as a living planet. John Wiley \& Sons inc., USA.

Koomen, E., Jasper D., Mark K., Piet, R. and Henk S. (2005). Valuation of Metropolitan Open Space; Presenting the Research Framework. Paper for the $45^{\text {th }}$ congress of the European Regional Science Association. Amsterdam, the Netherlands.

Nandi (2007). Solving Problems of Urban Environment through Green Space Management Optimization. Geography Department, UPI, Bandung.

Nugrahini, P. (2006). Urban Green Space. Agricultural Faculty, UPN "veteran", West Java.

Banjarbaru Municipality (2001). Local Regulation of Banjarbaru Number 5 Year 2001 on General Spatial Planning of Banjarbaru City.

Banjarbaru Municipality (2007). Vegetation Index Classes of Banjarbaru.

Banjarbaru Municipality (2007). A Map of shrub Land Covers in Banjarbaru.

Government of Indonesia Republic (2007). Regulation of Indonesia Republic Number 26 Year 2007 on Space Management.

Rawling, J. (2000). Managing Bushland Remnants in Urban Environment. Eleventh Australian Weeds Conference Proceedings. 348-353. 
Dienny R. Rahmani, Gunawan, Setia B. Peran : VARIATION IN VEGETATION COVER OF

Suarez, P.M., Fenn, M.E., Alcala, V.M.C.and Aldrete, A. (2007). The Effect of Canopy Cover on Through Fall and Soil Chemistry in Two Forest Sites in Mexico City Air Basin. Journal of Atmosfera. 83: 21-100.

Werdiningsih, H. (2007). Study on Green Space Patterns in Housing Environment Semarang. Scientific Journal of Urban and Housing Planning. 6: 87-96. 